\begin{tabular}{||l|l|l|}
\hline \multicolumn{2}{|c|}{ PublisherInfo } \\
\hline \hline PublisherName & $:$ & BioMed Central \\
\hline \hline PublisherLocation & $:$ & London \\
\hline \hline PublisherImprintName & $:$ & BioMed Central \\
\hline \hline
\end{tabular}

\title{
Comparison of different methods of HER-2 analysis in archival
} tissue

\begin{tabular}{|c|c|c|}
\hline \multicolumn{3}{|c|}{ ArticleInfo } \\
\hline ArticleID & : & 3764 \\
\hline ArticleDOI & : & $10.1186 /$ bcr-2001-68446 \\
\hline ArticleCitationID & : & 68446 \\
\hline ArticleSequenceNumber & : & 36 \\
\hline ArticleCategory & $:$ & Paper Report \\
\hline ArticleFirstPage & : & 1 \\
\hline ArticleLastPage & $:$ & 3 \\
\hline ArticleHistory & $:$ & $\begin{array}{ll}\text { RegistrationDate } & : 2001-8-20 \\
\text { Received } & : 2001-4-9 \\
\text { Accepted } & : 2001-8-20 \\
\text { OnlineDate } & : 2001-9-12\end{array}$ \\
\hline ArticleCopyright & $:$ & Biomed Central Ltd2001 \\
\hline ArticleGrants & $:$ & \\
\hline ArticleContext & : & 1305833 \\
\hline
\end{tabular}


Richard de Boer, ${ }^{\text {Affl }}$

Aff1 Austin and Repatriation Medical Centre, Melbourne, Australia

Keywords

FISH, HER-2 gene amplification, HER-2 overexpression, immunohistochemistry

\section{Context}

Overexpression of the HER-2 oncogene is likely to be both a prognostic and a predictive factor in patients with breast cancer. There is considerable controversy over the best way to test for tumour HER-2 status. This study analysed HER-2 status in archival breast cancer tissue, by assessing the immunohistochemical (IHC) sensitivity of a series of antibodies. HER-2 status was also determined by fluorescence in situhybridisation (FISH) of amplified genes.

\section{Significant findings}

The HER-2 gene was amplified in $28 \%$ of the tumours, whereas overexpression was seen in $26-42 \%$ of the tumours. Strongly positive IHC results $(3+)$ with any of the antibodies were always associated with gene amplification whilst weakly positive results $(2+)$ often were not. The authors concluded that tumours showing high levels $(3+)$ of overexpression on IHC testing almost certainly have gene amplification, but that FISH testing should be considered for tumours with lower levels of positive expression.

\section{Comments}

This is a well designed and well performed study that again highlights the potential problems with the use of IHC in testing for HER-2 protein overexpression (see Additional information [1][2]). It makes the 
interesting point that although the HercepTest has been approved by the US Food and Drug Administration for determining which patients should be offered anti-HER-2 therapy, the HercepTest was not in fact used to identify patients in the pivotal HerceptinR trials that led to the approval of its use. This paper emphasises the importance of the development of universal standardised techniques for HER-2 testing so that therapies can be targeted to patients with the highest chance of benefit.

\section{Methods}

Immunohistochemistry, FISH, paraffin sections

\section{Additional information}

1. Press MF, Hung G, Godolphin W, Slamon DJ: Sensitivity of HER-2/neu antibodies in archival tissue samples: potential source of error in immunohistochemical studies of oncogene expression. Cancer Res 1994, 54:2771-2777 (PubMed abstract).

2. Jimenez RE, Wallis T, Tabasczka P, Visscher DW: Determination of Her-2/Neu status in breast carcinoma: comparative analysis of immunohistochemistry and fluorescent in situ hybridisation [see comments]. Mod Pathol 2000, 13:37-45 (PubMed abstract).

\section{References}

1. Lebeau A, Deimling D, Kaltz C, Sendelhofert A, Iff A, Luthardt B, Untch M, Lohrs U: Her-2/neu analysis in archival tissue samples of human breast cancer: comparison of immunohistochemistry and fluorescence in situhybridization. J Clin Oncol . 2001, 19: 354-363. 